\title{
Comparison of gastropod mollusc (Apogastropoda: Hydrobiidae) habitats in two crater lakes in Nicaragua
}

\author{
Jeffrey K. McCrary ${ }^{1}$, Henry Madsen ${ }^{2}$, Liza González ${ }^{3}$, Inti Luna ${ }^{4}$ \& Lorenzo J. López ${ }^{5}$ \\ 1 College of Natural Resources, Virginia Tech, Blacksburg, VA 24061, and National Agricultural University, Managua, \\ Nicaragua; jmccrary2@yahoo.com \\ 2 Mandahl-Barth Research Centre for Biodiversity and Health in Developing Countries and DBL Center, Faculty of Life \\ Science, University of Copenhagen, Jaegersborg Allé 1D, DK2920 Charlottenlund, Denmark. \\ 3 National Engineering University, Managua, Nicaragua \\ 4 University of Central America, Apdo 69, Managua, Nicaragua \\ 5 FUNDECI/GAIA, Biological Research Station, Lake Apoyo Nature Reserve, Nicaragua
}

\section{Received 04-VII-2006. Corrected 26-III-2007. Accepted 08-VI-2007.}

\begin{abstract}
The aquatic gastropod mollusc, Pyrgophorus coronatus, may perform an important role in the transmission of an emergent ocular pathology among fishes in Lake Apoyo, Nicaragua. This disease emerged after an introduction of tilapia (Oreochromis niloticus) and the subsequent loss of Chara sp. beds in the lake. We compared the mollusc population densities in three habitats (sandy/muddy substrates, rocks, and Chara vegetation) at varying depths $(1.5,10,20$, and $30 \mathrm{~m})$ in two volcanic crater lakes in Nicaragua: Lake Apoyo and Lake Xiloa, where lower numbers of affected fishes were found and tilapia has not been introduced. Duplicate samples at $1.5 \mathrm{~m}$ depth were taken in each habitat monthly for a year, and triplicate samples for bathymetric analysis of snail populations were performed during August, 2005. Samples of fixed surface area were filtered in a $0.4 \mathrm{~cm}$ size screen and live snails were counted from each sample. The preferred snail habitat in both lakes, Chara beds, was vastly reduced in Lake Apoyo via consumption by introduced Nile tilapia (Oreochromis niloticus). Structureless sandy substrates (mean \pm standard error $3.1 \pm 1.3 \mathrm{ind} / \mathrm{m}^{2}$ ) had lower population densities than other habitats in Lake Xiloá (rocks $590.9 \pm 185.3 \mathrm{ind} / \mathrm{m}^{2}$; vegetation $3686.5 \pm 698.2 \mathrm{ind} / \mathrm{m}^{2}$; ANOVA I, $\mathrm{p}<0.01$ in both cases) but this difference was attenuated in Lake Apoyo (sand $384.4 \pm 111.1 \mathrm{ind} / \mathrm{m}^{2}$; rocks $1480.4 \pm 384.8$ ind $/ \mathrm{m}^{2} ; 0.01<\mathrm{p}<0.05$ ), where the snails on sandy bottoms were mostly embedded in filamentous algae coating this substrate. Snail population densities in Chara were lower at $20 \mathrm{~m}$ than more shallow depths in both lakes. Chara was not found at $1.5 \mathrm{~m}$ depth in Lake Apoyo, and was not present at $30 \mathrm{~m}$ depth in either lake. Shell lengths in rocky substrate in Lake Apoyo $(3.62 \pm 0.12 \mathrm{~mm})$ were greater than in Lake Xiloá $(2.39 \pm 0.12 \mathrm{~mm})$, suggesting differential snail predation levels in the lakes $(\mathrm{p}<0.005)$. Snail populations increased by $67 \%$ inside exclusion cages in sandy substrates in Lake Apoyo (paired $t$-test, $\mathrm{p}<0.05$ ), demonstrating the importance of foraging pressure on snail populations. Snail populations in open cages, on the other hand, were reduced by $23 \%$ $(\mathrm{p}<0.05)$, suggesting the importance of subacuatic structure in feeding areas for molluscivorous fishes. We found a significant preference toward Chara by the snails $(\mathrm{p}<0.05)$ and significant foraging pressure on them $(\mathrm{p}<0.05)$ in sandy/muddy substrates. The disruption of Chara by introduced tilapias in Lake Apoyo may play a role in the emergence of ocular pathologies in the lake. Rev. Biol. Trop. 56 (1): 113-120. Epub 2008 March 31.
\end{abstract}

Key words: Chara, cichlid, Pyrgophorus coronatus, tilapia, trematode, emergent disease.

Species richness and endemism among bony fishes in the Nicaraguan Great Lakes and the volcanic crater lakes near them have only recently begun to be appreciated. The crater lakes exhibit some of the classic characteristics of island ecology (Waid et al. 1999). The taxonomic and conservation status of these fishes are very poorly known. What is known, however, is that in some of the lakes where the fishes of this species complex are found, tilapia (Oreochromis spp.) have been recently introduced, resulting in destruction of the habitat 
for native fishes (McCrary et al. 2001) and reductions in native cichlid fish populations (McKaye et al. 1995). Introduced tilapia commonly prosper at the cost of native species wherever climate permits their reproduction (Canonico et al. 2005). However, ecological alterations caused by tilapia invasions are often not easily anticipated because of limited knowledge of food webs and disease propagation. A recent, sustained disease outbreak affecting fish species which are not even yet described in Lake Apoyo demonstrates the urgency of basic ecological information in these systems (McCrary et al. 2006).

Nile tilapia (Oreochromis niloticus (Linnaeus, 1758)) were cultivated in a floating cage operation in Lake Apoyo during the 1990's, from which escapees entered the lake and caused dramatic ecological alterations, particularly through the complete disappearance of Chara from the lake for at least four years (McCrary et al. 2001, McCrary et al. 2006). In the 1980's Oreochromis aureus (Steindachner, 1864) was introduced in another cage culture effort, but this species has not been detected in the lake since 1992 (McCrary et al. 2001). In 1991, a local fisherman transferred several individuals of the eleotrid Gobiomorus dormitor LaCépède, 1800 to Lake Apoyo from Lake Masaya, and exponential population growth of this lurking predator ensued (Tate et al. 2001). How native fish populations have responded to these introductions has not been determined, although anecdotal data suggest reduced fishery productivity has resulted (J.K. McCrary, unpubl.).

Our earlier interest in cichlid fish diversity and the impacts of tilapia introductions on it in Nicaraguan lakes led us to examine the snail communities in Lake Apoyo and Lake Xiloá, two water-filled volcanic calderas without any superficial aquatic outlet. They were formed by volcanic explosions around 20000 years ago.

The aquatic moluscan fauna in the substrate of both lakes is dominated by Pyrgophorus coronatus (Pfeiffer, 1840). Only one other aquatic species in found in Lake Xiloá in very low levels, and no other species has been found in Lake Apoyo. This gastropod species is small (around $3 \mathrm{~mm}$ shell length) and numerous in both lakes. No information exists on its ecology in either lake. However, snails such as this one may serve as hosts in the life cycles of metazoan parasites which in successive stages may also infect other animals such as fishes and birds (Vidal-Martínez et al. 2001). The ecology of this snail may be central to the recent emergence of disease in Lake Apoyo (McCrary et al. 2001), in which thousands of fishes have died after becoming blind and having their eyes plucked by other fishes, apparently infected by trematode parasites in the postocular region (McCrary et al. 2006). These parasites occupy fishes in the second, nonsexual life stage after passing from snails such as $P$. coronatus, with the final, sexual life stage occurring in the gut of aquatic birds. The cichlid fishes of this lake are demersal and many feed upon snails, making them candidates for heterophyid infections as well as agents of population control of the snails in these lakes.

The recent, abrupt changes in the lake food chain and community structure as a result of fish species introductions in Lake Apoyo warrant analysis of the lake ecology to determine whether any of the species of fishes in it are affected by the new environmental challenges presented. We present here results of the study of the basic analysis of the ecology of the freshwater snail $P$. coronatus, utilizing Lake Xiloa as a control lake for comparison in case of some aberration caused by the environmental changes imposed by the tilapias introduced in Lake Apoyo. This information is especially important because it may reveal whether the snails of Lake Apoyo have been stressed by the introduction of tilapias, which may be a factor in the high incidence of blindness in the lake. We examined aquatic snail habitat use in Lake Apoyo and in Lake Xiloá, where no species introductions have occurred recently. We report here the snail population densities found in the three habitats (Chara, rocks, and $\mathrm{sand} / \mathrm{mud}$ ), and at various water depths from $1.5 \mathrm{~m}$ to $30 \mathrm{~m}$. We also analyzed the impact of snail predation in sandy/muddy substrates 
by measuring the impact of exclusion cages on snail populations.

\section{MATERIALS AND METHODS}

Samples were gathered in $0.08 \mathrm{~m}^{2}$ areas in sandy/muddy bottoms and $0.02 \mathrm{~m}^{2}$ areas in Chara and rocky bottoms, with a metal strainer of size $200 \mathrm{~mm}$ diameter with mesh opening size approximately $0.4 \mathrm{~mm}$. In each habitat type found in Lake Xiloa and Lake Apoyo, duplicate samples were taken monthly from July 2004 to June 2005. Sample sites were on the north shore of Lake Apoyo and on the south shore of Lake Xiloa. Snails were counted and shell height for each live snail was measured to the nearest $0.1 \mathrm{~mm}$. In August 2005, we measured the snail population density with triplicate samples using the above methodology at depths of $1.5 \mathrm{~m}, 10 \mathrm{~m}, 20 \mathrm{~m}$, and $30 \mathrm{~m}$ in both lakes, in each habitat type. Samples at greater than $1.5 \mathrm{~m}$ depth were obtained using SCUBA.

We also considered the impacts of foraging on sandy/muddy substrates in Lake Apoyo, by measuring the snail population densities in exclusion cages which prevent the entry of molluscivorous fishes. One cage type had five sides covered with plastic mesh with $1 \mathrm{~cm}$ maximum mesh opening size. This cage was placed over substrate with the open side down, creating a $1 \mathrm{~m}^{3}$ excluded space. The other cage type had four sides covered. This cage served as a control, because fishes could enter the cage freely although light was partially blocked from the substrate from the mesh on the upper side of the cage. The cages were placed at $10 \mathrm{~m}$ depth over sandy bottom, and left 10-14 days, at which time snail sizes and population densities were determined inside the cages and in the free space at a distance of at least $3 \mathrm{~m}$ from the cages.

Snail population densities reported are number of live individuals per meter squared substrate area. Shell sizes are reported in $\mathrm{mm}$. Error presentations are standard errors of the mean for twelve monthly observations in the habitat preference comparison, for three measurements at each depth in the bathymetric study, and for five measurements in the exclusion cage analysis. Statistical significance of differences was determined using ANOVA I for unmatched samples, except where stated that a paired t-test was used.

\section{RESULTS}

Only P. coronatus adults were collected in this study. Chara was the preferred habitat for snails in Lake Xiloa $(\mathrm{p}<0.001)(3686.5 \pm 698.2$ $\mathrm{ind} / \mathrm{m}^{2}$ ) with more than six times the population density per unit surface area than found in rocks $\left(590.9 \pm 185.3 \mathrm{ind} / \mathrm{m}^{2}\right)$, and more than 1 000 times the population density found in sand/ mud substrate $\left(3.1 \pm 1.3 \mathrm{ind} / \mathrm{m}^{2}\right)$ (Fig. 1). The rock substrate contained more snails than the sand/mud substrate in Lake Xiloa $(\mathrm{p}<0.01)$. The rock substrate in Lake Apoyo (1 480.4 \pm 384.8 ind $/ \mathrm{m}^{2}$ ) held a population density more than twice that of Lake Xiloa ( $<<0.05)$, although the snail population density found in the sand/mud substrate in Lake Apoyo (384.4 $\pm 111.1 \mathrm{ind} / \mathrm{m}^{2}$ ) was more than one hundred times that found in Lake Xiloa $(p<0.01)$. This difference is likely accounted for by the copious layer of filamentous algae (cyanobacteria) covering most of the sandy/muddy substrate in Apoyo, in which we observed the majority of these snails were found. Snail sizes did not vary significantly by habitat within lakes ( $>0.10)$, but were significantly larger in rocky substrate in Lake Apoyo $(3.62 \pm 0.12 \mathrm{~mm})$ than in Lake Xiloa $(2.39 \pm 0.12$ $\mathrm{mm})(\mathrm{p}<0.005$; Fig. 2).

Snail population densities in Chara beds were lower at $20 \mathrm{~m}$ than at more shallow depths in Lake Xiloa (Fig. 3A; p $<0.01$ ). A similar trend was noted in Lake Apoyo, but the difference was not statistically significant (Fig. 3B; $\mathrm{p}<0.10$ ). No Chara was found in either lake at $30 \mathrm{~m}$ depth. In Lake Apoyo, no Chara vegetation was found at $1.5 \mathrm{~m}$ depth and only limited patches were found at other depths (Fig. 3B). Snail shell lengths did not vary at different depths (Fig. 4A and 4B; $\mathrm{p}>0.05$ ).

Snail populations in sandy/muddy substrates at $10 \mathrm{~m}$ water depth increased sig- 


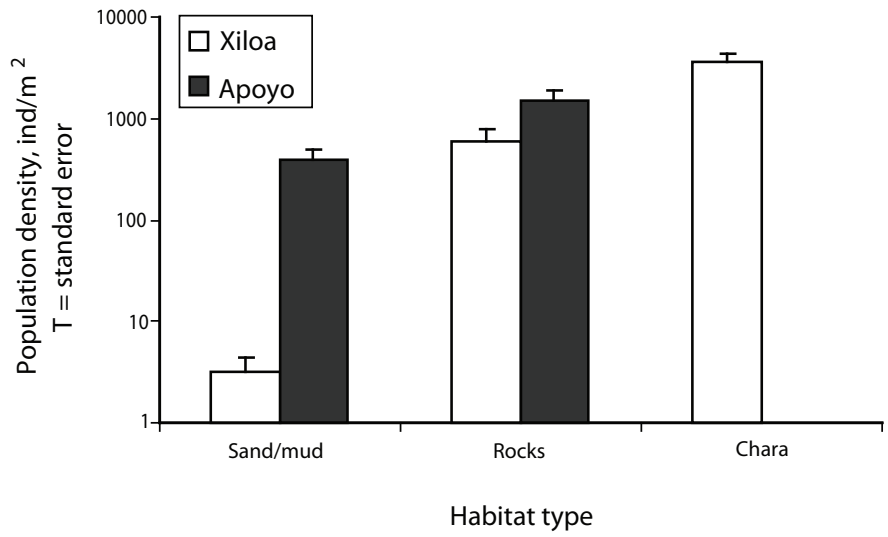

Fig. 1. Population density of Pyrgophorus coronatus at $1.5 \mathrm{~m}$ depth, by habitat, in Lake Xiloa and in Lake Apoyo. Standard errors of the mean shown for twelve monthly measurements $(n=12)$.

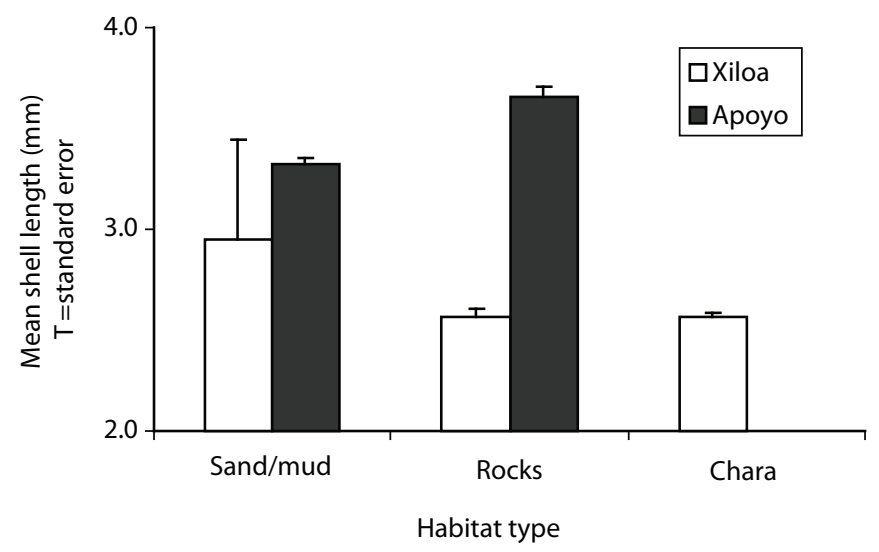

Fig. 2. Shell length of Pyrgophorus coronatus at $1.5 \mathrm{~m}$ depth, by habitat in Lake Xiloa and Lake Apoyo. Standard errors of the mean shown for the following numbers of individuals: Xiloa-sand/mud, n=4; rocks, $\mathrm{n}=285$; Chara, $\mathrm{n}=1$ 779; Apoyosand/mud, $n=699$; rocks, $n=549$.

nificantly when the substrate was excluded from fish predation 10-14 days by application of exclusion cages $(67 \pm 37 \%$; paired $t$-test, $\mathrm{p}<0.05)$; they were reduced significantly $(23 \pm 11 \%$; paired $t$-test, $\mathrm{p}<0.05)$ in open cages applied for the same period (Fig. 5). In three of the five closed-cage experiments, juvenile $G$. dormitor were encountered inside the cages, apparently attracted by the structure of the cage and able to pass through the $1 \mathrm{~cm}$ mesh openings. In all of the open-cage experiments, small fishes including G. dormitor and Midas cichlids were encountered in or near the open cages. These observations are consistent with the general tendency of the demersal species of this lake to remain near structures, presumably to protect against piscivorous predators such as Parachromis managuensis (Günther, 1868).

\section{DISCUSSION}

Although tilapia does not consume the aquatic snails found in these lakes (McCrary et al. 2001), its presence in Lake Apoyo has impacted the $P$. coronatus populations by 


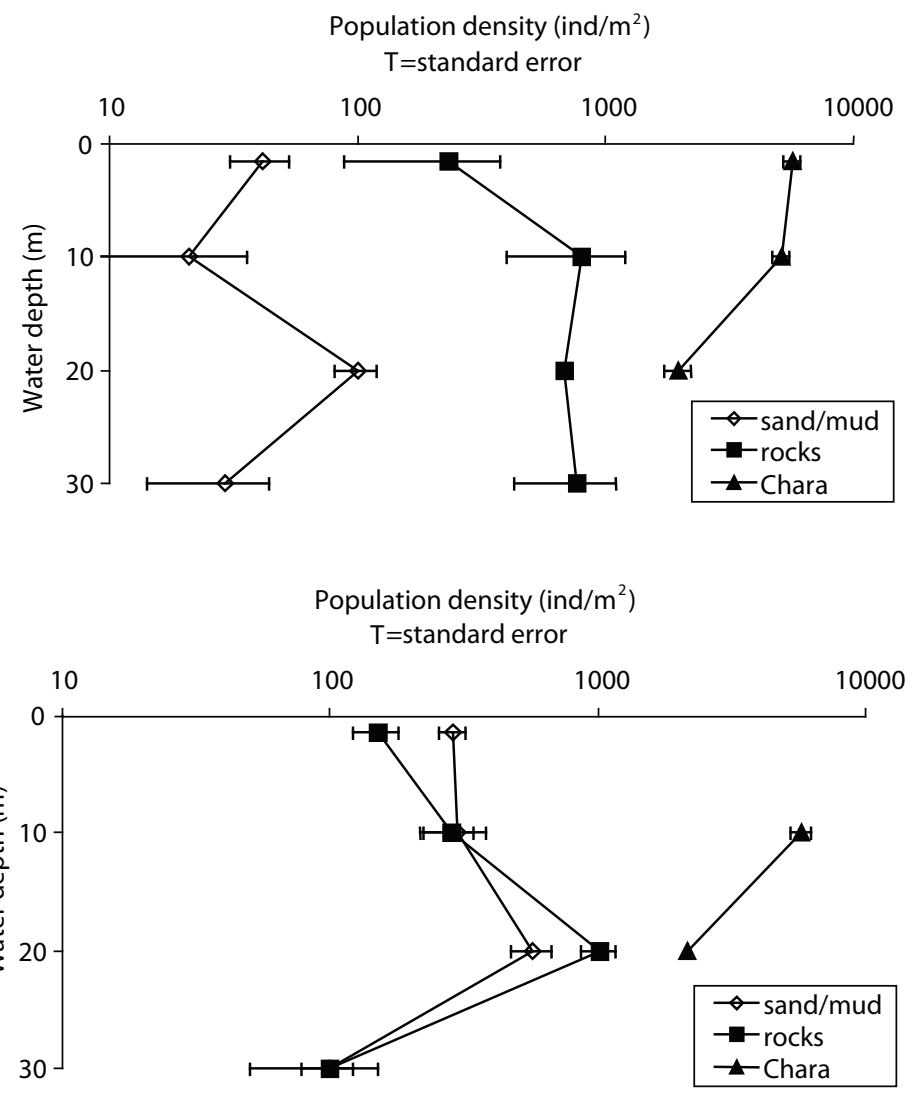

Fig. 3. Population density of Pyrgophorus coronatus at varying water depths according to habitat type in Lake Xiloa (A) and Lake Apoyo (B). Standard errors of the mean for three measurements shown $(n=3)$.

eliminating their preferred habitats throughout most of the lake. The snails have responded to the environmental changes by inhabiting the filamentous algae which has proliferated over most sandy and muddy substrates in the limnetic zone once dominated by Chara. All four taxa of the Midas cichlid species complex from Lake Apoyo consume significant quantities of molluscs and filamentous algae along with the snails (J.K. McCrary, unpubl.). The question is raised as to whether fishes are debilitated by poisonous secondary metabolite accumulation from consumption of this component of the Lake Apoyo ecosystem, which was apparently much more reduced before 1996, when Chara was plentiful in the lake. The impacts of consumption of filamentous algae on the immune system of these fishes, permitting blindness to occur, merit further investigation.

There are more molluscivorous fish species and greater density of fishes in Lake Xiloa (McKaye 1977), likely driving the adult molluscs to smaller average sizes than in Lake Apoyo. The larger shell size for snails in Lake Apoyo also implies older snail ages which may play a role in the heterophyid infection levels in the lake.

By far the most important habitat for $P$. coronatus in both lakes is the presence of Chara, at all depths analyzed. The quantity of Chara during our study period in Lake Apoyo was very limited, but where found, it was prime Pyrgophorus habitat. This clearly demonstrates a link between tilapia presence which relates to 

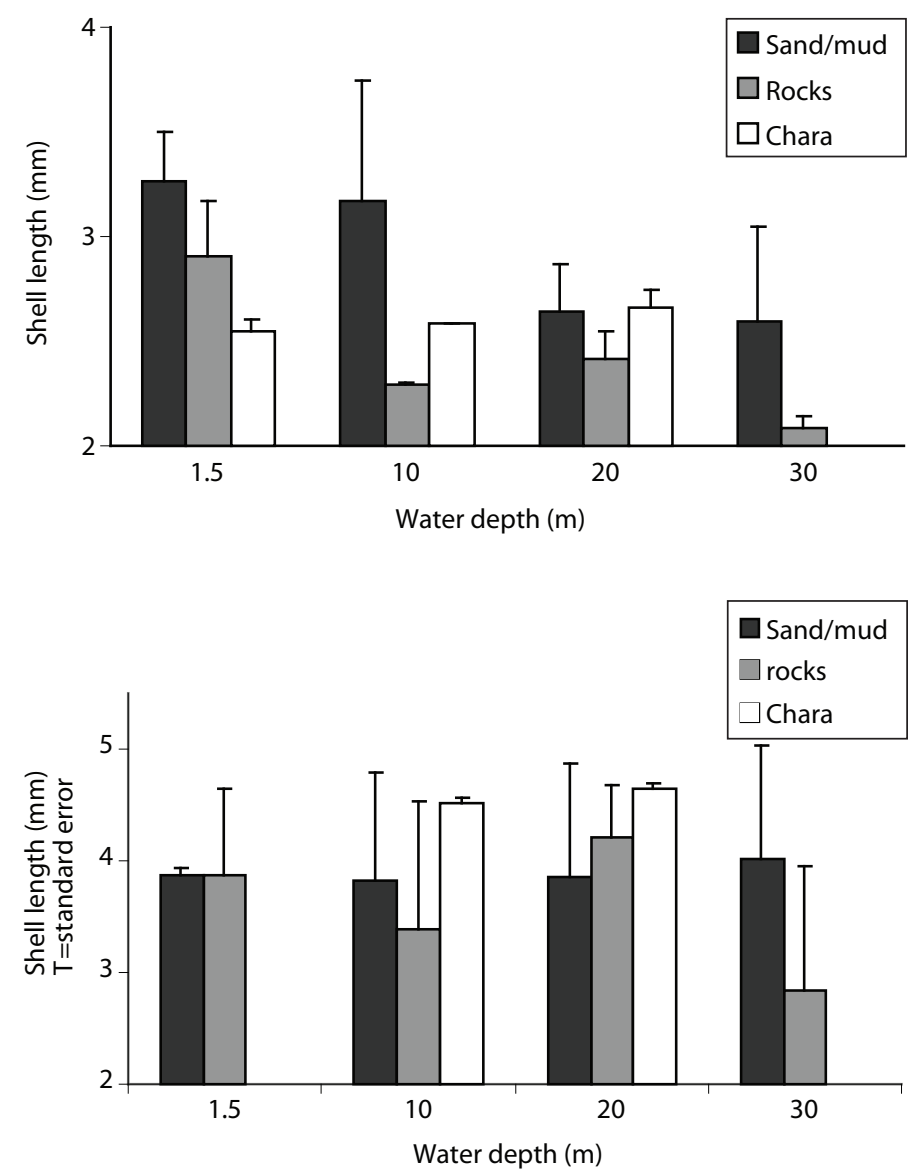

Fig. 4. Shell length of Pyrgophorus coronatus at varying water depths according to habitat type in Lake Xiloa (A) and in Lake Apoyo (B). Standard errors of the mean shown for the following sample sizes at each respective lake and depth: Xiloasand/mud, $1.5 \mathrm{~m}, \mathrm{n}=10 ; 10 \mathrm{~m}, \mathrm{n}=5 ; 20 \mathrm{~m}, \mathrm{n}=24 ; 30 \mathrm{~m}, \mathrm{n}=7$; Xiloa-rocks, $1.5 \mathrm{~m}, \mathrm{n}=14 ; 10 \mathrm{~m}, \mathrm{n}=48 ; 20 \mathrm{~m}, \mathrm{n}=41 ; 30 \mathrm{~m}, \mathrm{n}=46$; Xiloa-Chara, $1.5 \mathrm{~m}, \mathrm{n}=339 ; 10 \mathrm{~m}, \mathrm{n}=308 ; 20 \mathrm{~m}, \mathrm{n}=118$; Apoyo-sand/mud, $1.5 \mathrm{~m}, \mathrm{n}=69 ; 10 \mathrm{~m}, \mathrm{n}=72 ; 20 \mathrm{~m}, \mathrm{n}=137 ; 30 \mathrm{~m}$, $\mathrm{n}=24$; Apoyo rocks, $1.5 \mathrm{~m}, \mathrm{n}=9 ; 10 \mathrm{~m}, \mathrm{n}=17 ; 20 \mathrm{~m}, \mathrm{n}=61,30 \mathrm{~m}, \mathrm{n}=6$; Apoyo-Chara, $10 \mathrm{~m}, \mathrm{n}=345 ; 20 \mathrm{~m}, \mathrm{n}=129$.

the destruction of Chara and the populational health of $P$. coronatus, whose preferred habitat in both lakes is Chara. Clearly, numbers of snails in Lake Apoyo are lower in response to the disappearance of Chara, and they are occupying inferior habitats.

Although snail predation rates by fishes are likely much higher in Lake Xiloa than in Lake Apoyo, the snail removal rate via predation by molluscivores in Lake Apoyo may be a controlling factor in snail population density, especially in sandy/muddy substrates, as was demonstrated by the exclusion cage experi- ments. Statistically significant increases in snail population density were observed in the closed cages. On the other hand, the structure provided by open cages likely provided an attractive foraging site for the molluscivorous fishes, resulting in statistically significant decreases in snail population densities in the open cages.

These results demonstrate that the fishes of Lake Apoyo which we analyzed depend upon $P$. coronatus as an important dietary component and in turn these fishes depend upon Chara to provide good habitat for this species. In addi- 


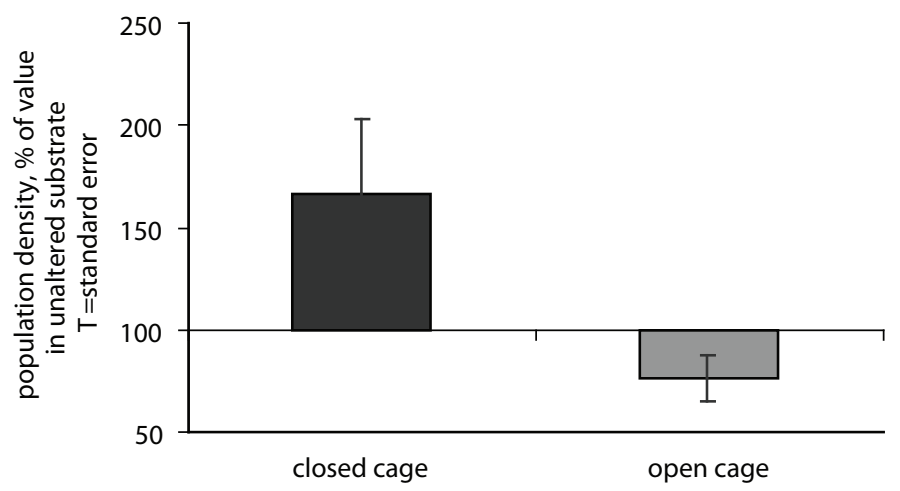

Fig. 5. Relative population density of Pyrgophorus coronatus in muddy/sandy substrate in Lake Apoyo, in closed exclusion cages and open exclusion cages at $10 \mathrm{~m}$ water depth. Values given are relative to population density in unaltered sandy/ muddy substrate. Standard errors of the mean shown for five observations $(n=5)$.

tion, the high consumption levels of filamentous algae (Cyanophyta), probably co-consumed in foraging for mollusks, leads to suspicion of accumulation of toxic compounds in the fishes which may provoke immunodeficiency which may implicate a higher rate of infection by trematodes in the lake. Cyanophyta are known to contain toxic substances (Albay et al. 2005, Jos et al. 2005), and it merits mention that the carpet of this substance in Lake Apoyo corresponds approximately with the disappearance of Chara, and does not exist in Lake Xiloa. We hypothesize that exposure to cyanobacteria metabolites may provoke heightened trematode infection rates in the molluscs or may immunosupress the fishes, or both.

This study also demonstrates the complex nature of environmental impacts of human activities such as introductions of exotic species in freshwater aquatic ecosystems. The impacts of tilapia on the ecosystem in Lake Apoyo were not predictable in detail, because very little knowledge is available on this type of event to date. More research is needed on this subject in locations such as Lake Apoyo in order to develop better knowledge bases on the subject. The environmental changes which have recently occurred in Lake Apoyo subsequent to tilapia introductions have resulted in impacts such as a five- to six- year disappearance of Chara, which in itself may be sufficient to have caused fish species extinctions in the lake due to habitat loss, in addition to other repercussions. Here we demonstrate the importance of Chara as habitat for one of the important elements of the food web in the lake, P. coronatus.

\section{ACKNOWLEDGMENTS}

This study was provided by funding and support from DANIDA, FUNDECI/Gaia, and the Ministry of Natural Resources and the Environment of Nicaragua.

\section{RESUMEN}

El gasterópodo acuático, Pyrgophorus coronatus, podría jugar un papel importante en la transmisión de una patología ocular emergente entre los peces de la laguna de Apoyo, Nicaragua. Esta enfermedad surgió después de una introducción de tilapia (Oreochromis niloticus) y la subsecuente pérdida de lechos de Chara sp. en la laguna. Comparamos las densidades poblacionales del caracol en tres hábitats (substratos arenosos/lodosos, rocas y vegetación de Chara) en dos lagunas cratéricas volcánicas en Nicaragua: La laguna de Apoyo y la laguna de Xiloá, donde no se encuentraron grandes cantidades de peces afectados y donde no se han introducido tilapias. Mensualmente, por un año tomamos muestras duplicadas 
a $1.5 \mathrm{~m}$ profundidad mensualmente por un año, y durante agosto de 2005, muestreos triplicados de las poblaciones del molusco, para análisis batimétrico $(1.5,10,20$ y 30 $\mathrm{m})$. Para determinar el número de individuos por unidad de área superficial, las muestras fueron filtradas en un colador de $0.4 \mathrm{~cm}$ de apertura de malla y contamos los moluscos vivos en cada muestra. El hábitat preferido de los caracoles en ambas lagunas fue la vegetación de Chara, que en la laguna de Apoyo fue vastamente reducida al ser consumida por las tilapias nilóticas introducidas (Oreochromis niloticus). Los substratos arenosos, menos estructurados que los otros sustratos estudiados, tuvieron densidades poblacionales más bajas (media \pm error estándar $3.1 \pm 1.3 \mathrm{ind} / \mathrm{m}^{2}$ ) que en los otros hábitats en la laguna de Xiloá (vegetation $590.9 \pm 185.3 \mathrm{ind} / \mathrm{m}^{2}$; rocas 3 $686.5 \pm 698.2 \mathrm{ind} / \mathrm{m}^{2}$; ANOVA I, $\mathrm{p}<0.01$ en ambos casos) pero esta diferencia fue atenuada en la laguna de Apoyo (arena $384.4 \pm 111.1 \mathrm{ind} / \mathrm{m}^{2}$; rocas $1480.4 \pm 384.8 \mathrm{ind} /$ $\mathrm{m}^{2} ; 0.01<\mathrm{p}<0.05$ ), donde los moluscos sobre los fondos arenosos habitan una capa de algas filamentosas sobre el substrato. La densidad poblacional en Chara fue más baja a $20 \mathrm{~m}$ profundidad que en sitios más someros de ambas lagunas. No encontramos Chara a $1.5 \mathrm{~m}$ de profundidad en la laguna de Apoyo, tampoco la encontramos a $30 \mathrm{~m}$ de profundidad en ambas lagunas. Las conchas de los gasterópodos en rocas fueron más largas en la laguna de Apoyo $(3.62 \pm 0.12 \mathrm{~mm})$ que en la laguna de Xiloá $(2.39 \pm 0.12 \mathrm{~mm})(\mathrm{p}<0.005)$, lo que sugiere distintos niveles de depredación de moluscos en las dos lagunas. En la laguna de Apoyo, las densidades poblacionales sobre los sustratos arenosos se aumentaron por $67 \%$ dentro de las jaulas de exclusión $(\mathrm{p}<0.05)$ sobre los substratos arenosos en la laguna de Apoyo, manifestando la importancia de la presión por depredación sobre las poblaciones de moluscos en este hábitat. Sin embargo en jaulas abiertas, las poblaciones del caracol fueron $23 \%$ menores que en areas sin jaulas $(\mathrm{p}<0.05)$, destacando la importancia de estructuras subacuáticas en las areas de alimentación de peces moluscívoros. Encontramos una preferencia significativa hacia Chara $(\mathrm{p}<0.05)$ y presión de depredación significativa $(\mathrm{p}<0.05)$ en los substratos arenosos/lodosos. La pérdida de vegetación de Chara por la actividad alimenticia de las tilapias introducidas en la laguna de Apoyo puede jugar un papel importante en la emergencia de patologías oculares en los peces de la laguna.

Palabras clave: Chara, cíclido, Pyrgophorus coronatus, tilapia, tremátodo, enfermedad emergente.

\section{REFERENCES}

Albay, M., A. Matthiensen \& G.A. Codd. 2005. Occurrence of toxic blue-green algae in the Kucukcekmece Lagoon (Istanbul, Turkey). Env. Toxicol. 20: 277-284.

Canonico, G.C., A. Atherington, J.K. McCrary \& M.L. Thieme. 2005. The effects of introduced tilapias on native biodiversity. Aquat. Cons. 15: 463-483.

Jos, A., S. Pichardo, A.I. Prieto, G. Repetto, C.M. Vazquez, I. Moreno \& A.M. Camean. 2005. Toxic cyanobacterial cells containing microcystins induce oxidative stress in exposed tilapia fish (Oreochromis sp.) under laboratory conditions. Aquat. Toxicol. (Amsterdam) 72: 261-271.

McCrary, J.K., E.P. van den Berghe, K.R. McKaye \& L.J. López. 2001. Tilapia cultivation: a threat to native fish species in Nicaragua. Encuentro 58: 9-19.

McCrary, J.K., B.R. Murphy, J.R. Stauffer, Jr. \& S.S. Hendrix. 2006. Tilapia (Teleostei: Cichlidae) status in Nicaraguan natural waters. Environ. Biol. Fish. 78: 107-114.

McKaye, K.R. 1977. Competition for breeding sites between the cichlid fishes of Lake Jiloá, Nicaragua. Ecology 58: 291-302.

McKaye, K.R., J.D. Ryan, J.R. Stauffer, Jr., L.J. López P, G.I. Vega \& E.P. van den Berghe. 1995. African tilapia in Lake Nicaragua: Ecosystem in transition. BioScience 45: 406-411.

Tate, B.A., K.R. McKaye, E.P. van den Berghe, L.J. López P. \& D.H. Secor. 2001. Initial six-year expansion of an introduced piscivorous fish in a tropical Central American lake. Biol. Inv. 3: 391-404.

Vidal-Martínez, V.M., M.L.A. Macedo, T. Scholz, D.G. Solís \& E.F.M. Franco. 2001. Atlas of the Helminth Parasites of Cichlid Fish of Mexico. Academia, Prague, Czech Republic.

Waid, R., R.S. Raesly, K.R. McKaye \& J.K. McCrary. 1999. Zoogeografía íctica de las lagunas cratéricas de Nicaragua. Encuentro 51:65-80. 